This item is the archived peer-reviewed author-version of:

Equality without improvement? A case study of the impact of the Belgian unified status among bluecollar and white-collar workers on their occupational pensions

\title{
Reference:
}

Knoops Sarah.- Equality without improvement? A case study of the impact of the Belgian unified status among blue-collar and white-collar workers on their occupational pensions

European journal of social security - ISSN 1388-2627 - 2021, p. 1-21

Full text (Publisher's DOI): https://doi.org/10.1177/13882627211031932

To cite this reference: https://hdl.handle.net/10067/1799990151162165141 


\title{
Equality without improvement?
}

\section{A case study of the impact of the Belgian unified status among blue- collar and white-collar workers on their occupational pensions}

\author{
Author: \\ Sarah Knoops \\ Faculty of Law, University of Antwerp, Belgium \\ Corresponding Author: \\ Sarah Knoops, Faculty of Law, University of Antwerp, Venusstraat 23,V.181, 2000 Antwerpen, \\ BELGIUM. \\ Email: sarah.knoops@uantwerp.be
}

\begin{abstract}
The long-standing EU acquis of equal pay between male and female workers still proves to be a source of inspiration in the fight against discrimination, even in matters beyond the EU's competence. This article deals with differences in status between blue- and white-collar workers, which have been haunting many member states even as technological progress erodes its justification. Although this ground was never protected by EU law, a case study of the Belgian unified status with regard to occupational pensions (the second pension pillar), clearly shows the impact of the jurisprudence of the CJEU. In line with this EU case law, there is no requirement to grant the most beneficial pension scheme to all employees, which could lead to equal but nevertheless very modest occupational pensions. Based on the preliminary results, we can predict that the Belgian unified status will have a positive effect on the number of blue- and white-collar workers affiliated to a pension scheme. It is, however, unlikely that the high level of benefits of the most generous pension schemes will be retained after harmonisation, considering the financial impact on the employer. It is therefore to be expected that the unified status will indeed lead to equal occupational pension schemes between blue- and whitecollar workers, but fail to act as a lever to improve the quality of the second pension pillar in Belgium.
\end{abstract}

\section{Keywords}

occupational pensions, EU, Belgium, non-discrimination, equal pay, the quality of the second pension pillar, the Belgian unified status among blue and white-collar workers

\section{Introduction}

The CJEU has consistently confirmed that contributions to an occupational pension scheme fall within the material scope of both the principle of equal pay (article 157 TFEU) ${ }^{1}$ and the other work-related EU anti-discrimination laws ${ }^{2}$ (Ravelli, 2012: 52-54; Bogg et al., 2016: 117). When a pension scheme is found

\footnotetext{
${ }^{1}$ C-170/84 Bilka ECLI:EU:C:1986:204, para 22; C-262/88 Barber ECLI:EU:C:1990:209, para 30; C-57/93 Vroege ECLI:EU:C:1994:352; C-4/02 and C-5/02 Schönheit and Becker ECLI:EU:C:2003:583; C-395/08 Bruno ECLI:EU:C:2010:329.

2 Inter alia the Part-time Work Directive (Directive 1997/81/EC), the Fixed-term Work Directive (Directive 1999/70/EC) and the Framework Equality Directive (Directive 2000/78/EC). C-267/06 Maruko ECLI:EU:C:2008:179, para 56; C-268/06 Impact ECLI:EU:C:2008:223, para 115 and paras 131-134; C-147/08 Römer 
to be discriminatory, the consequences of this infringement differ depending on the period of service. To know what legal redress a discriminated worker is entitled to, it is crucial to distinguish the different periods of service concerned. On the one hand, the CJEU ${ }^{3}$ clearly explained that pending the adoption of the necessary measures reinstating equal treatment (the Barber window ${ }^{4}$ ), persons in the disadvantaged category must be granted the same advantages enjoyed by persons in the favoured category. With the discriminatory pension scheme being the only valid point of reference, levelling up is compulsory (Masselot and McLellan, 2018: 487-488). On the other hand, the CJEU has confirmed in numerous cases that for periods of service completed after the adoption of measures reinstating equal treatment, the principle of equal pay does not require harmonisation at the highest level of pay. ${ }^{5} \mathrm{As} \mathrm{EU}$ law does not impose any specific level of pay, thus allowing a pension scheme to be adjusted to a lower level of benefits provided these are no longer discriminatory, it remains to be seen whether nondiscrimination laws can actually lead to improved occupational pension schemes.

In this article, I aim to offer insights into this issue, focusing on the specific distinction between bluecollar and white-collar workers in Belgian occupational pension schemes. It starts with an analysis of the Belgian unified status among blue- and white-collar workers in labour law (2.1), then considers this issue with respect to occupational pensions (2.2). Although blue- and white-collar work is not a protected ground under EU non-discrimination law, the Belgian unified status regarding occupational pensions is inspired by the long-standing EU acquis of equal pay and non-discrimination law in general. In line with the jurisprudence of the CJEU, there is no requirement to grant the most beneficial pension scheme to all employees, which could lead to equal but nevertheless very modest occupational pensions. The unified status in the Occupational Pension Law (OPL) requires that as from 2025, all distinctions between blue- and white-collar workers with regard to occupational pensions should be abolished (2.3). As we are approaching the 2025 deadline, a thorough evaluation of efforts towards the harmonisation of occupational pensions is highly desirable (3). In the next section, we will elaborate on the quality of the second pension pillar in Belgium and how it could be impacted by the unified status (4). The final section concludes (5).

\section{The unified status among blue-collar and white-collar workers}

The imminent changes in the field of occupational pensions cannot be fully understood without looking more closely at the division between blue-collar and white-collar workers from a socio-historical and labour law perspective. Before addressing the impact on second pillar pensions, we will therefore briefly outline the unified status within labour law.

ECLI:EU:C:2011:286, para 36; C-443/15 Parris ECLI:EU:C:2016:897, para 33; C-171/18 Safeway ECLI:EU:C:2019:839.

3 C-184-89 Nimz ECLI:EU:C:1991:50, paras 18-20; Coloroll, paras 31-32; Smith, para 17; C-7/93 Beune ECLI:EU:C:1994:350, para 53; C-28/93 Van den Akker ECLI:EU:C:1994:351, para 17; C-147/95 Evrenopoulos ECLI:EU:C:1997:201, paras 42-43.

${ }^{4}$ The Barber window extends from 17 May 1990, the date of the Barber judgment on equal retirement ages for men and women in occupational pension schemes, until the date of the measures designed to achieve equal treatment. C-262/88 Barber ECLI:EU:C:1990:209.

${ }^{5}$ C-408/92 Smith ECLI:EU:C:1994:349, para 21; C-28/93 Van den Akker ECLI:EU:C:1994:351, para 19. This jurisprudence was also upheld with regard to discrimination claims based on the Framework Equality Directive: C-396/17 Leitner ECLI:EU:C:2019:375, paras 77-78. 


\subsection{The origin of the unified status within labour law}

At the beginning of the $20^{\text {th }}$ century, as the main character of their economies was shifting from agrarian to industrial, Belgium, along with other member states such as Germany, Luxembourg, France and Sweden, adopted a division in labour and social law on the grounds of being a blue-collar or a whitecollar worker (Strauss, 2013: 347; Doyen, 2014: 272). It was common practice in those countries to subdivide employees according to the nature of their tasks. Employees performing mainly intellectual work were labelled white-collar workers, while those performing mainly manual labour were tagged blue-collar workers. ${ }^{6}$

Moreover, in many EU member states labour and social security law developed at different paces as between blue-collar and white-collar workers. Quite paternalistically, the need for legal protection for blue-collar workers was assessed as being more urgent (Debaenst, 2004: 66-67). In Belgium, too, bluecollar workers were the first to benefit from labour and social law, while white-collar workers had to wait considerably longer to enjoy legal protection. ${ }^{7}$ This division between blue- and white-collar workers was all-encompassing, ranging from statutory pensions and holiday legislation to major differences in the Employment Contracts Act with respect to unfair dismissal, notice periods and trial periods. $^{8}$

Although this distinction may be understandable within its historical context, it can only be deemed obsolete today. After all, with the introduction of new hard-and software in the workplace, many jobs have become increasingly complex, requiring both intellectual and manual effort. Spurred by this eroding distinction, national constitutional courts have increasingly insisted on legislative amendments towards a unified status for all employees. In Germany, the constitutional court concluded as long ago as 1990 that the differential treatment of blue- and white-collar workers in labour law was outdated and discriminatory. ${ }^{9}$

In Belgium, however, differential treatment in labour law was only successfully contested as discriminatory in 2011. Moreover, the Belgian constitutional court judged it to be outdated and no longer tenable only from 2013 on. ${ }^{10}$ Eliminating this discriminatory treatment still proved to be a laborious process requiring intensive consultation between the social partners, eventually resulting in a statutory unified status which introduced a new harmonised system of notice periods, trial periods

\footnotetext{
${ }^{6}$ Art. 2 and 3 Law of 3 July 1978 concerning employment contracts, Belgian Official Journal 22 August 1978.

7 Law of 10 March 1900 on the employment contract for blue-collar workers, Belgian Official Journal 14 March 1990; Law of 7 August 1922 on the employment contract for white-collar workers.

${ }^{8}$ Law of 3 July 1978 concerning employment contracts, Belgian Official Journal 22 August 1978.

${ }^{9}$ Bundesverfassungsgericht 30 May 1990, 82, 126.

10 This judgement was based on the principle of equality and non-discrimination in the Belgian Constitution (articles 10 and 11), which is general in scope and prohibits any form of legal discrimination, irrespective of its grounds (Grondwettelijk Hof 7 July 2011, No 125/2011. Previous cases: Arbitragehof 8 July 1993, No 56/93; Arbitragehof 21 June 2001, No 84/2001). Similar to its Belgian counterpart, the Luxembourg constitutional court was reluctant to condemn this division as discriminatory (Cour Constitutionnelle 18 June 2004, 21/04 and 22/04; Cour Constitutionnelle 25 May 2007, 40/07).
} 
and unfair dismissal. ${ }^{11}$ Although these modifications were perceived as revolutionary, they did not eliminate the distinction itself. To this day, the Employment Contracts Act persists in distinguishing between blue- and white-collar workers based on the nature of the work performed. ${ }^{12}$ The next sections will reveal that, in comparison to the unified status in labour law, the Belgian legislator decided on a more ambitious legal framework for occupational pensions.

\subsection{Differences between blue-and white-collar workers in voluntary occupational pensions}

In Belgium, as in most European countries, the pension system is supported by different pension pillars. Added to the statutory pension (first pillar), a growing number of employees benefits from an occupational pension (second pillar). An important feature differentiating occupational from statutory pensions is their voluntary character, giving employers and industries the freedom whether or not to offer occupational pensions (Nys et al., 2017: 188). This voluntary character is also reflected in the Belgian Occupational Pension Law (OPL), ${ }^{13}$ which regulates almost all aspects of the second pension pillar for employees. If a Belgian employer wishes to offer such a pension scheme, they can do so through a unilateral decision (article $5 \mathrm{OPL}$ ) or a collective bargaining agreement at the company level (article $7 \mathrm{OPL}$ ). In addition to these company pension schemes, the social partners at the industry level can launch a sector-wide pension scheme by means of a collective bargaining agreement (article $8 \mathrm{OPL}$ ).

As there is no obligation to install an occupational pension scheme, or to extend it to all employees, the principle of non-discrimination plays a pivotal role (Denys et al., 2020: 41). Employers and industries can decide autonomously on the scope of their occupational pension schemes, albeit within the limits of non-discrimination law (article $14 \mathrm{OPL}$ ).

Historically, this freedom frequently led to the material scope of pension schemes being limited to either blue-collar or white-collar workers (Stevens, 2008: 437). Although this may seem odd nowadays, it perfectly reflects the pre-2010 zeitgeist in Belgium. The preparatory works of the OPL itself ${ }^{14}$ promoted distinctions known in labour law as legitimate categories of affiliates, inspiring many employers to limit the scope of their pension scheme accordingly to either blue-collar or white-collar workers (Doyen, 2014: 272). In addition, the way in which the social partners are organised at the industry level has led to the further embedding of differential treatment of blue- and white-collar workers. In Belgium, industrial relations have been highly institutionalised and protected by law since 1968. ${ }^{15}$ In implementation of this law, several Joint Labour Committees (JLC) were created or reaffirmed by Royal Decree, each with its own scope based on the main activity performed by companies within

\footnotetext{
${ }^{11}$ Law of 26 December 2013 on the introduction of a unified status between blue-collar and white-collar workers with regard to notice periods and the sick day and accompanying measures, Official Journal 31 December 2013; Collective Bargaining Agreement No. 109 of 12 February 2014 on the statement of reasons for dismissal.

12 Art. 2 and 3 Law of 3 July 1978 concerning employment contracts, Official Journal 22 August 1978.

13 Law of 28 April 2003 concerning occupational pensions and the tax system of such pensions and of certain additional social security benefits, Belgian Official Journal 15 May 2003.

14 Preparatory works OPL, Chamber 2000-2001, nr. 50-1340/001, 38.

15 These statutory JLCs have a bipartite composition with assistance from a neutral chairperson from the federal public service. They play an active role in negotiating employment conditions and concluding sectoral collective bargaining agreements, which can have a general binding effect granted by Royal Decree, as is often the case (Law of 5 December 1968 on collective labour agreements and Joint Labour Committees, Official Journal 15 January 1969).
} 
an industry. Unfortunately, within many industries the competence of social partners was further divided between separate JLCs for blue- and white-collar workers respectively (Engels, 1992: 732). More than 50 years later, this still means that most JLCs are competent for either blue-collar or whitecollar workers, leaving the complex system of social dialogue still permeated by the duality between blue- and white-collar workers. ${ }^{16}$ As a consequence, an occupational pension scheme installed by a JLC with a separated competence would, by definition, be limited in scope to either blue-collar or whitecollar workers.

This tradition of differentiating between blue-collar and white-collar workers' pension schemes was cut short by the 2013 law on the unified status for occupational pensions.

\subsection{The statutory unified status for occupational pensions}

It is important to emphasise that the constitutional court never ruled on the discriminatory nature of occupational pension schemes, as it lacks the competence to rule on the matter. In contrast to the aforementioned legal divisions in labour law, the differences in pensions schemes are not upheld in occupational pension law itself but are the results of autonomous decisions by employers or industries. Although the 2011 judgment of the Belgian constitutional court with regard to labour law therefore had no direct effect on pension schemes, it did indirectly spark a revolution in occupational pensions (Delogne, 2014: 185). In 2014, the scope of the OPL's non-discrimination clause was broadened to preclude any distinction between blue-collar and white-collar workers in pension schemes from 2025 onwards (unified status in occupational pensions). ${ }^{17}$ This change affects a large number of pension schemes, given that the traditional distinction between blue- and white-collar workers used to be considered a safe choice in the past (Pâques, 2017: 3-4).

To mitigate this major impact, the OPL allowed the gradual abolition of the distinction over a ten-year period. Three subsequent phases can be distinguished within this process:

\footnotetext{
${ }^{16}$ At 20 December 2019, only 39 JLCs had a mixed competence (blue-collar and white-collar workers), while 62 JLCs had a competence that was limited: 40 JLCS were competent only for blue-collar workers and 22 JLCS only for white-collar workers. These numbers show a gradual but very slow harmonisation of social partners on the industry level (Liste des organes paritaires à la date du 20 décembre 2019 (Numac: 2020040085), Official Journal 6 February 2020).

17 Article 14/1-14/4 Law of 28 April 2003 on occupational pensions and on the tax regime applicable to such pensions and to certain additional social security benefits, hereafter referred to as Occupational Pension Law (OPL), inserted by the Law of 26 December 2013 on the introduction of a unified status between blue-collar and white-collar workers with regard to notice periods and the sick day and accompanying measures, Official Journal 31 December 2013.
} 


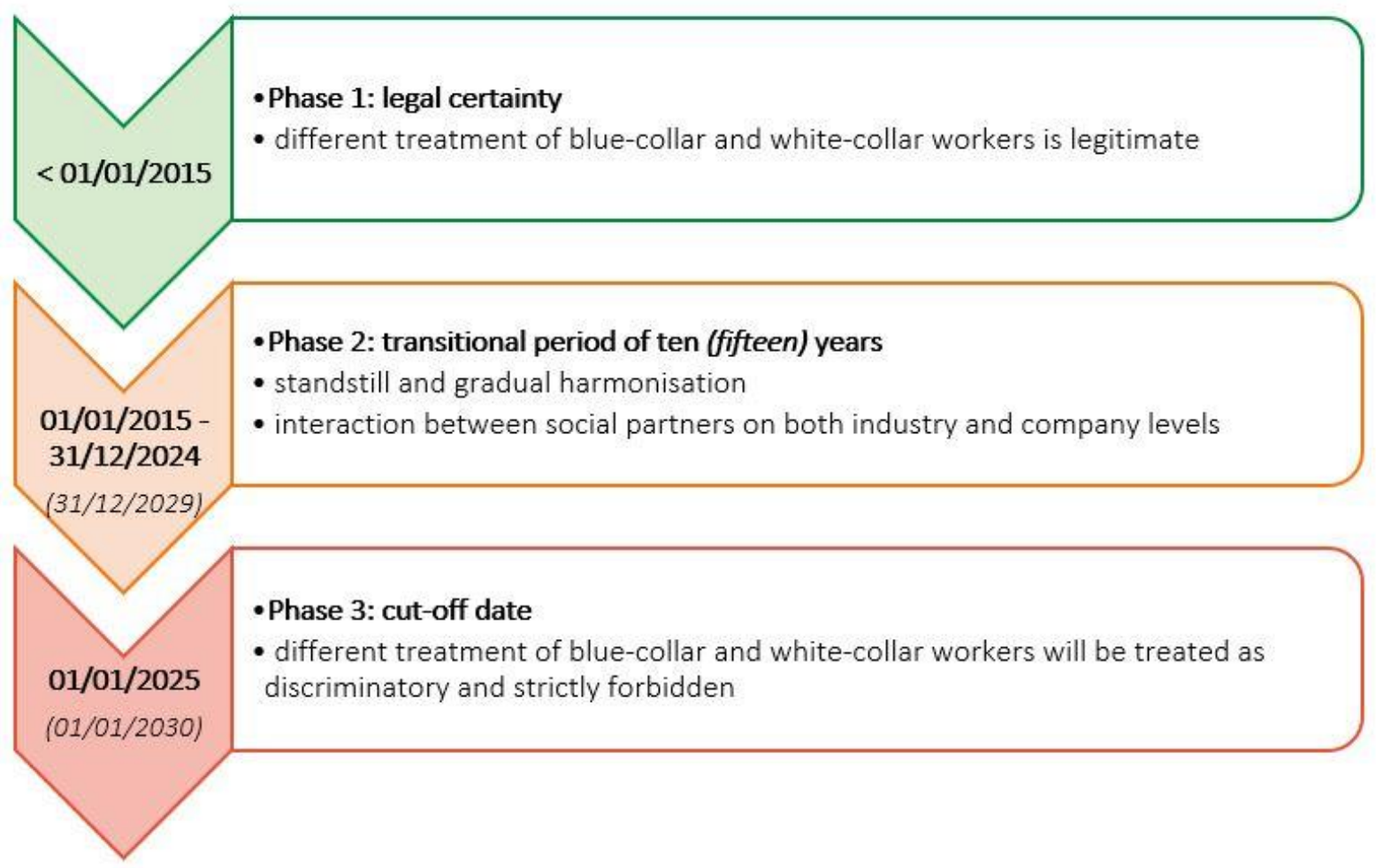

Figure 1. The legal framework of the Belgian unified status for occupational pensions.

Firstly, the law provided much-needed legal certainty by confirming that a difference in treatment between blue-collar and white-collar workers for periods of service up until 1 January 2015 was legitimate (Doyen, 2014: 273). Since 2015, a standstill period applies in combination with a harmonisation process of ten years. Within this time frame, former differences between blue- and white-collar workers can be preserved, but new differences will only be allowed when closing the gap. The OPL relies heavily on the social partners on both company and industry levels to accomplish a full harmonisation of the occupational pension schemes. This gradual process towards full harmonisation was to be finished by 2025. For periods of service from 1 January 2025 on, all differences between blueand white-collar workers were to be strictly forbidden and considered discriminatory.

Very recently, on 8 June 2021, the social partners reached a draft agreement to postpone the cut-offdate to 1 January 2030. This postponement by five years, which brings the total transitional period to 15 years, shows once again the difficulty in eliminating this firmly rooted distinction between blue- and white-collar workers from the Belgian legal system. The draft agreement still needs to be approved by the government and will require a formal legislative amendment of the OPL. Pending the actual legislative changes, it is difficult to anticipate all the specifics of the amendment. Bearing these concerns in mind, the already known details will be included in this article.

Inspired by the EU equal pay acquis, ${ }^{18}$ the three subsequent phases of the Belgian unified status refer to different periods of service (Knoops, 2020: 250). The choice of this point of reference is in keeping with the accrual nature of occupational pensions over the long term. ${ }^{19}$ In this way, account can rightly be taken of the evolutionary nature of the concept of discrimination, so that the financial impact of an

\footnotetext{
${ }^{18}$ C-262/88 Barber ECLI:EU:C:1990:209.

${ }^{19}$ C-152/91 Neath ECLI:EU:C:1993:949, para 14.
} 
alteration in judgement remains within limits. By referring to periods of service, a historical distinction can be sustained for the periods in the past in which the distinction was still considered permissible, while it will no longer be tolerated in the future (Delogne, 2014: 185). In contrast with the EU equal pay acquis, the Belgian unified status does not require an immediate and full achievement of equality. During the transitional period, the OPL allows for a progressive harmonisation and leaves the organisers of the pension schemes with a choice between immediate harmonisation and a more gradual approach (De Somviele and Van Damme, 2014: 159). This is a particular advantage over the clear stance of the CJEU $^{20}$ against a progressive achievement of equality that still maintains discrimination, even if only temporarily (Masselot and McLellan, 2018: 487-488).

In contrast to the statutory unified status in Belgium, Luxembourg avoided any legal intervention regarding harmonisation between blue- and white-collar workers in occupational pensions and opted for a voluntary approach instead (Berns and Schmit, 2009: 117; Doyen, 2014: 272). The Luxembourg legislator stated in the preparatory works of the unified status law that adjustments to the pension system were necessary, but that it was up to the social partners at company level to explore such adjustments. ${ }^{21}$ With this statement the legislator offered the reassurance that there was certainly no automatic extension of the pension schemes to all employees, and that this extension could only be achieved through a formal amendment of the pension regulations. ${ }^{22}$ To facilitate these adjustments, the unified status law softened compulsory enrolment to allow for a distinction between existing and new members of a pension scheme. ${ }^{23}$ It thereby acknowledged that the previous legislation, which did not provide for such a difference, could hamper the thorough reform of pension schemes (Van Peer and Hélard, 2009: 160). This policy choice not to proceed to legal harmonisation was warmly welcomed by employers. ${ }^{24}$ Sweden also avoided legal intervention and chose to leave this division within occupational pensions intact (Strauss, 2013: 347; Ulander-Wänman, 2019: 488).

\section{The impact of the unified status on Belgian occupational pensions}

As mentioned above, the original unified status law will probably be amended to offer more time to the social partners. This need for change already demonstrates the large impact of the Belgian unified status on occupational pensions. In this section, I will review the progress made by the social partners so far and assess in detail which characteristics of pension schemes need to be harmonised. Before addressing these issues, however, it is important to emphasise that the unified status does not guarantee a favourable outcome.

\subsection{No obligation to level up}

As clarified in the introduction, even after discriminatory treatment EU non-discrimination law does not prescribe a certain level of remuneration for the measures that restore equal treatment. In line with the EU equal pay acquis, the Belgian unified status regarding occupational pensions does not prescribe

\footnotetext{
${ }^{20}$ C-408/92 Smith ECLI:EU:C:1994:349, paras 25-27; C-171/18 Safeway ECLI:EU:C:2019:839, para 24.

${ }^{21}$ Draft law on the unified status for private sector employees, Chamber 2006-2007, no. 5750/00, 11.

22 Draft law on the unified status for private sector employees, Chamber 2006-2007, no. 5750/00, 101.

${ }^{23}$ Art. 3 Law of 15 May 2008 on the unified status for private sector employees, Mémorial A60.

24 Draft law on the unified status for private sector employees, Chamber 2006-2007, no. 5750/02, 30. 
a levelling up between blue-collar and white-collar workers. Rather, the legislator placed its trust in the social partners to achieve a level of harmonisation that they deemed fit, allowing them to choose either the least or the most favourable regime, or instead opt for a middle ground (Pâques, 2017: 5). To benefit from this autonomy, the social partners will have to close the deal by 1 January 2025 (probably to be extended to 1 January 2030). For periods of service after this cut-off-date, differential treatment of blue- and white-collar workers will be deemed discriminatory and occupational pension schemes for them expected to be equal. ${ }^{25}$ If the social partners do not succeed in attaining harmonisation as from this cut-off-date, the unified status will demand a levelling up to the most favourable scheme, which is also in keeping with EU case law concerning the so-called 'Barber window'.

Despite these similarities with the equal pay cases, too many parallels should not be drawn with the issue of an equal retirement age for men and women, as required by Barber, when making a cautious prediction of the most popular choices regarding the unified status among blue- and white-collar workers. As far as the retirement age is concerned, there is after all a major interference from the legislator's attempts to prolong the active employment of workers. In Belgium, early access to occupational pension schemes is particularly restricted ${ }^{26}$ in order to encourage the pursuit of a full career up to the legal pensionable age (Devoet, 2019: 131). In this perspective, the retirement age in occupational pension schemes is commonly raised to 65 years or more, which could be interpreted as a general 'legal levelling down' of the pension cover and, alternatively, to a 'legal levelling up' for death cover (when provided). Regarding the unified status of blue- and white-collar workers, there is no such legal interference and the level at which pension schemes will be harmonised remains unpredictable.

Anticipating that the unified status could cause a levelling down and being aware that a shorter time frame could deter employers and industries that had already opted for an occupational pension, the Belgian legislator provided a ten-year transitional period (De Somviele and Van Damme, 2014: 153154). ${ }^{27}$ This was a sensible policy decision because if these early enthusiasts opted to abolish their pension schemes to comply with the unified status, this could seriously harm the second pension pillar. Likewise, it is to be expected that the government will endorse the recent agreement of the social partners to prolong the transitional period to 15 years. This extended time frame should certainly enable the social partners to change their mindset and pursue a more favourable solution through a social dialogue that could benefit all employees.

\subsection{Progress and intermediate evaluation}

The monitoring system implemented by the OPL (article 14/4, §2) allows us to make a preliminary assessment of the progress made during phase 2. Every JLC has the legal obligation to report

\footnotetext{
${ }^{25}$ The period of employment during phase 2 of the unified status (01/01/2014 to 31/12/2024) could be compared with the period of employment before the Barber case, i.e. before 17 May 1990. The cut-off date in the Barber case was 17 May 1990, whereas it will be 1 January 2025 for the unified status (probably to be extended to 1 January 2030).

${ }^{26}$ Law of 18 December 2015 guaranteeing the sustainability and social character of occupational pensions and strengthening the supplementary nature in relation to retirement pensions, Official Journal 24 December 2015.

27 Draft law on the unified status in occupational pensions, Chamber 2013-2014, no. 53-3399/002, 20 and 36.
} 
biannually ${ }^{28}$ to the National Labour Council (NLC), ${ }^{29}$ which evaluates the state of the harmonisation process at industry level to encourage the industries to complete this process on time. ${ }^{30}$ Meanwhile, the intermediate reports keep the companies informed of the current state of affairs and provide us with an insight into the progress made in each sector (Doyen, 2014: 274).

\section{Progress at the industry level}

Closely examining the progress made so far by the JLCS, one has to conclude that much remains to be done during the final stage. Social partners at industry level were to have reached a collective bargaining agreement on the harmonisation of their industry-wide occupational pensions by 1 January 2023. For the implementation of these agreements, they had two more years as the imposed deadline was 1 January 2025. Only one period of wage negotiations away from the deadline, this matter was most urgent. However, the new draft agreement of 8 June 2021 grants the industries more time to achieve this goal. The draft agreement would postpone the deadline on the industry level to 1 January 2027, giving the JLCS four extra years to reach a collective bargaining agreement. The cut-off date to implement the harmonisation would move to 1 January 2030.

Overall, the progress so far made by the industries has been rather disappointing, especially since the social partners were so closely involved in the drafting of the law. It would be fair to state that the organisational structure of the JLCS has severely hindered the process of harmonising industry-wide pension schemes (Pâques, 2017: 7). As mentioned above, a majority of JLCs are still restricted to either blue-collar or white-collar workers, meaning that they are forced to look for their counterpart JLC before they can start a dialogue on harmonisation. Moreover, with these committees not being organised symmetrically, finding an interlocutor for the harmonisation process has proven to be quite a challenge.

So far, only a limited number of industries have achieved harmonisation. Firstly, almost all mixed JLCS (competent for both blue-collar and white-collar workers) with a pension scheme made no distinction between blue-collar and white-collar workers, thereby complying instantly with the unified status. The mixed JLCs in the Flemish Non-Profit Industry, ${ }^{31}$ for example, grant a pension scheme that does not

\footnotetext{
${ }^{28}$ The JLCS need to report to the NLC on 01/01/2016, 01/01/2018, 01/01/2020 and 01/01/2022. The impact of the new draft agreement on these dates is still unclear.

29 The NLC is an independent body in public law, with members equally divided between representatives of employers' associations and trade unions (Law of 29 May 1952 establishing the National Labour Council, Official Journal 31 May 1952). The council has the power to conclude collective bargaining agreements that cover all private sector industries, a power which they use extensively (Article 7 Law of 5 December 1968 on collective labour agreements and Joint Labour Committees, Official Journal 15 January 1969). Its main function is to advise a Minister or parliament on general issues of a social nature. Within this competence, the NLC will assist the Minister of Labour and the Minister of Pensions in successfully monitoring the progress made in every industry towards compliance with the unified status. In addition, the NLC can also deliver an opinion on disputes arising between JLCS.

${ }^{30}$ The NLC has six months after the submission of the JLCS' reports to make an evaluation before it has to report to the Ministers on 1 July 2016, 1 July 2018, 1 July 2020 and 1 July 2022. The impact of the new draft agreement on these dates is still unclear.

${ }^{31}$ Being a more recent sector, JLC 318.02, JLC 319.01, JLC 327.01, JLC 329.01, JLC 330 and JLC 331, commonly referred to as the 'Flemish Non-Profit Industry', were mixed from the start and find their roots in the Royal Decree of 2 April 1973, Official Journal 23 June 1973. Engels (1992: 732).
} 
differentiate on the basis of workers' status (NLC, 2020: 12). Secondly, certain non-mixed JLCs had already decided, even before the unified status was adopted, no longer to distinguish between blueand white-collar workers regarding their occupational pension. In the chemical industry, for example, the symmetrically organised JLCs 116 (blue-collar) and 207 (white-collar) adopted a defined contribution pension scheme with an identical contribution of 0.85 per cent of the salary declared at the National Social Security Office, with a quarterly minimum of 57.41 euros (NLC, 2020: annex 3). As these industries treat blue- and white-collar workers equally with regard to their occupational pensions, they already comply with the final phase of the unified status.

Other industries may not yet have reached full harmonisation, but have clearly moved towards a more equal pension scheme. As expected, industries that are organised in a symmetrical way are making faster progress then those that are confronted with an asymmetrical area of application. The symmetrical JLCs in the food industry (JLC 118 and JLC 220) and in the metal industry (JLC 111 and JLC 209) took successive steps to eliminate differences between blue- and white-collar workers, bringing a fully harmonised pension scheme within reach (NLC, 2020: annex 2-3). As far as the asymmetrical industries are concerned, only a few have made a concerted effort to take the necessary steps to harmonise their pension schemes. In the transport sector, a number of smaller JLCs for blue-collar workers (JLC 140.03 and JLC 140.04) chose to align their pension scheme with the scheme of the larger JLC for white-collar workers (JLC 226) (NLC, 2020: annex 6-7). This strategic choice has paid off, as the harmonisation is currently in its final stage. ${ }^{32}$ However, since the decision was made not to establish a joint pension scheme through a multi-sectoral organiser, it remains a particular concern not to lose the harmonisation achieved. To maintain a harmonised pension scheme, a close monitoring of the pension scheme of JLC 226 is crucial as there is no automatic alignment. To ascertain an automatic alignment, some industries aim to merge the blue-collar and white-collar JLCs, ${ }^{33}$ although it will be interesting to see whether this ambitious objective can still be achieved in time, even within the extended deadline. On a positive note, those industries that have already made progress in bridging the gap between pension schemes for blue- and white-collar workers generally chose to grant a levelling up for the disadvantaged group. ${ }^{34}$

Other industries did not succeed in making (significant) progress towards harmonising their pension schemes. A frequently expressed explanation for this delay is the above-mentioned asymmetric area of competence of most JLCS, which has made finding the right interlocutors a strenuous task. In terms of the number of interlocutors, the auxiliary JLC for white-collar workers (JLC 200) is in the lead, with no fewer than 54 overlapping joint committees and sub-committees at present. Fortunately, JLC 200 recently agreed on a collective bargaining agreement that should facilitate harmonisation with their

\footnotetext{
32 Collective Bargaining Agreement of 17 May 2018 and of 22 November 2018 in JLC 140 (registration number 146632 and 149433), annex 2, Official Journal 16 July 2018 and 18 December 2018; Collective Bargaining Agreement of 26 September 2019 in JLC 140.04 (registration number 154722), Official Journal 4 November 2019.

33 JLCs 132, 144 and 145, competent for blue-collar workers in 'green industries', want to transfer the white-collar workers belonging to this industry from their current JLC (mostly JLC 200) to the blue-collar JLCS (NLC, 2020: annex 6-8).

${ }^{34}$ In the food industry (JLC 118 and 220), this levelling up resulted in a 1.65 per cent wage contribution in the DC scheme. Other examples of harmonisation at the most beneficial level can be found in the metal industry (JLCS 111 and 209) and the transport sector (JLCs 140.03 and 206).
} 
corresponding JLCS competent for blue-collar workers. ${ }^{35}$ This agreement allows social partners to create a customised pension scheme for white-collar workers per business activity so as to match the pension schemes granted in the corresponding blue-collar JLC. Hopefully, this agreement to install subsectoral pension schemes with a limited scope will be sufficient to break the deadlock promptly and inspire social partners to (re)start their harmonisation process.

In view of this slow progress on the industry level, further developments in the coming years were highly anticipated. The 2023 deadline still appeared to be attainable, provided that the social partners made every effort to achieve it. Nevertheless, some industries expressed legitimate concerns about the feasibility of the 2023 deadline, taking the economic crisis caused by the covid-19 pandemic into account. These concerns were heard and led to the recent draft social agreement with a postponement of the deadline to 2027. However, the government will expect the JLCS to immediately engage actively in the further harmonisation of their pension schemes, as progress to date has been below expectations. ${ }^{36}$

\section{Progress at the company level}

According to the currently applicable provisions of the OPL, employers can wait for the industry-wide agreements on harmonisation before finally adjusting their own pension schemes between 2023 and 2025. If the government ratifies the social partners' draft agreement of 8 June 2021, employers will be granted one extra year to harmonise their pension schemes (1 January $2027-1$ January 2030). In the meantime, they are given a heads-up by the industry reports. As the time they have left to finish the harmonisation process after the industries are done is limited, employers should be well prepared. To fully understand what adjustments are necessary, a clear overview of the characteristics that fall within the scope of the unified status is indispensable.

\section{Characteristics of pension schemes to be harmonised}

The National Labour Council (NLC) has listed the characteristics of pension schemes that need to be harmonised in order to address some of the concerns raised by the social partners about the implementation of the unified status in practice (NLC, 2019). In defining these characteristics, the NLC was inspired by the acquis of the long-standing legal protection against gender discrimination in EU law.

Firstly, occupational pension scheme type is an important feature that needs to be harmonised. When comparing the pension schemes for blue-collar and white-collar workers, the social partners may be confronted with various types of scheme currently in place. The unified status requires that the same pick be made for blue-collar and white-collar workers in terms of the type of pension commitment: either a defined contribution plan (DC) or a defined benefits plan (DB). The organiser's commitment to a DC or a DB plan will determine the focus of further harmonisation (NLC, 2019: 20), just like it would within the context of the principle of equal pay for men and women (Masselot and McLellan, 2018:

\footnotetext{
${ }^{35}$ Article 4 of the Collective Bargaining Agreement of 1 July 2019 in JLC 200 (registration number 152849), Official Journal 5 August 2019.

${ }^{36}$ In that respect, the draft agreement includes an obligation for the social partners to spend at least 0.1 per cent of the available wage margin on the harmonisation of occupational pensions. About this margin, see footnote 52 .
} 
490; Mbala Lutama, 2019: 250). ${ }^{37}$ When the employer has committed to a pension contribution (DC), this contribution must be equal. ${ }^{38}$ By contrast, an organiser who has promised a pension benefit (DB) must equalise the benefit. In Belgium, it is permitted within a DB plan to grant either annuities or a lump sum, each of which must be equal. ${ }^{39}$

Secondly, the wage components are characteristics that fall within the scope of the unified status and need to be harmonised (NLC, 2019: 22). As previously indicated, the wage calculation for both statutes will remain different because the distinction between blue- and white-collar workers still exists in labour and social security law. For example, a blue-collar worker will continue to be remunerated on an hourly basis, while a white-collar worker will be entitled to a monthly salary and their holiday pay also differs. The pension regulations should therefore describe an equal wage concept and use the same wage components to calculate the contribution for the occupational pension (DC) or the pension benefit (DB) (De Somviele and Van Damme, 2014: 157).

Thirdly, it is less clear whether premiums for risk coverage are characteristics that fall within the scope of the unified status. To determine whether the impact of risk premiums could be discriminatory, the lessons learned from gender discrimination provide guidance. Pension institutions use mortality tables to calculate the risk premium for death cover and for converting capital into interest (or vice versa). In the past, the mortality tables systematically made a distinction between men and women, without questioning it. However, these gender-dependent mortality tables were banned following the CJEU's Test-Achats ruling. ${ }^{40}$ In the context of individual life insurance, it ruled that when a man and a woman had to pay a different cost for a death cover, the non-discrimination principle was violated. Also in the context of statutory social security, the CJEU condemned these gender-dependent actuarial factors as discriminatory. ${ }^{41}$ It is remarkable, however, that in occupational pensions gender differences based on actuarial data concerning life expectancy are still admissible. ${ }^{42}$ Potentially, the broader debate on gender identity could provide new momentum to switch to unisex mortality tables in the second pension pillar as well. In line with this reasoning, it also seems obsolete to distinguish blue-collar and white-collar workers with regard to risk premiums. A future-proof policy should base its risk premiums on a sound analysis free from potential prejudices linked to the status of the employee, even when the unified status does not explicitly state this. Furthermore, it would be hard to reconcile a different cost for risk coverage with the unified status if it could have an impact on the remaining pension contribution (DC) (Sommerijns, 2009: 246-247). It is therefore appropriate to harmonise this characteristic of the pension scheme as well, although this stance is still disputed by the social partners in the NLC (NLC, 2019: 25-26).

\footnotetext{
${ }^{37}$ Article 9. h) and j) Directive 2006/54/EC of The European Parliament and of The Council of 5 July 2006 on the implementation of the principle of equal opportunities and equal treatment of men and women in matters of employment and occupation (recast), OJ 2006 L 204.

${ }^{38}$ C-152/91 Neath ECLI:EU:C:1993:949, para 31.

${ }^{39}$ Neath, paras 25-34.

${ }^{40}$ C-236/09 Test-Achats ECLI:EU:C:2011:100. See: Mbala Lutama, D. (2019: 239-245).

${ }^{41}$ C-318/13 X ECLI:EU:C:2014:2133. See: Mbala Lutama, D. (2019: 245-248).

42 Article 9. h) Directive 2006/54/EC; Report from the Commission on the application of Council Directive 2004/113/EC implementing the principle of equal treatment between men and women in the access to and supply of goods and services, COM/2015/0190 final, 10.
} 


\section{Intermediate evaluation}

At the moment it is still hard to predict the precise impact of the unified status on Belgian occupational pensions since a lot still needs to be done to reach a full harmonisation between blue- and white-collar workers. At first sight, the choice of some industries to level up could have a positive effect on the quality of occupational pensions in Belgium. Nevertheless, one must avoid drawing premature conclusions about agreements at the industry level by extending these results to the company level because the lower level of contributions in the former compared to the latter might explain the willingness to opt for an upward harmonisation. Notwithstanding these reservations, it would be interesting to make a cautious prediction as to whether the unified status among blue- and white-collar workers is likely to improve the quality of occupational pensions in Belgium.

\section{Potential improvement of the Belgian second pension pillar under the unified status}

In this section, the current quality of second pillar pensions in Belgium will be assessed, alongside the predicted effect of the unified status. This analysis will be based on two parameters which refer to how the OPL aimed to strengthen occupational pensions and make them more 'democratic'. ${ }^{43}$ Firstly, I examine how many employees have access to the second pension pillar (participation rate), as this is essential to achieving a 'democratic' second pension pillar. I go on to discuss the level of the granted benefits, as this element is equally crucial in determining the quality of the second pension pillar. Since there is no obligation to include all employees, or to grant a certain level of benefits, this raises concerns about the quality of occupational pensions for employees. It therefore remains an open question whether the unified status will prove to be effective in improving the quality of the second pension pillar, especially as, in full accordance with CJEU case law, there are no guarantees of upward harmonisation.

Figure 2 below offers a brief overview of both parameters as at 1 January 2020:

\begin{tabular}{|l|r|r|}
\hline \multicolumn{2}{|c|}{ Company } & \multicolumn{1}{c|}{ Industry } \\
\hline $\begin{array}{l}\text { Number of pension } \\
\text { schemes }\end{array}$ & 116,595 & 78 \\
\hline $\begin{array}{l}\text { Number of } \\
\text { affiliates }\end{array}$ & $1,991,464$ & $2,113,657$ \\
\hline $\begin{array}{l}\text { Average vested } \\
\text { reserves (€) }\end{array}$ & 27,237 & 2,475 \\
\hline
\end{tabular}

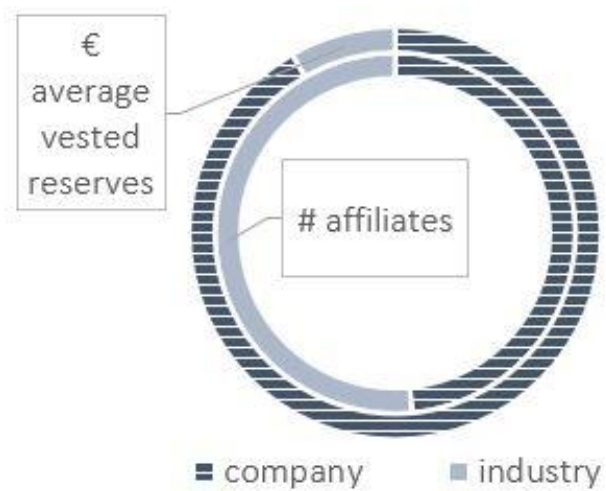

Figure 2. Comparison of the quality of Belgian occupational pensions on the company and industry levels, based on FSMA, 2020: 8.

\footnotetext{
${ }^{43}$ Preparatory works OPL, Chamber 2000-2001, nr. 50-1340/001, 17.
} 


\subsection{The participation rate and the category of affiliates}

In this section we will elaborate on the accessibility of the second pension pillar for employees. Did the OPL succeed in making occupational pension schemes accessible to the largest number of employees?

\section{Current state of play}

One of the innovative elements of the 2003 OPL was the clear authorisation of industry-wide pension schemes in order to increase participation rates. These schemes have a broad scope in terms of the number of affiliates, while company schemes often have a limited circle of solidarity. Because of the larger circle of affiliates, an industry-wide scheme could bring about more equality than a combination of company schemes.

Current figures do indeed show that this objective has been achieved. In 1999, only 30 per cent of the employee population were affiliated to a pension scheme (De Brabanter et al., 2004: 181). This participation rate has increased spectacularly over the years: in 2020, 63 per cent of active employees were affiliated to a supplementary pension scheme (FSMA, 2020: 6). The increase has been a direct result of the wide circle of affiliates in industry-wide schemes: with only 78 industry-wide schemes compared to 116,595 company schemes, they cover approximately the same number of affiliates (Figure 2).

\section{Possible impact of the unified status}

The unified status will most likely lead to an increase in the coverage ratio at the industry level, since the scope of industry-wide pension schemes for blue-collar workers is often broadened to include white-collar workers. However, industries can allow employers to opt out of an industry-wide scheme for their white-collar workers in accordance with article 9 OPL if they have previously installed a pension scheme for their white-collar workers at company level and prefer to avoid double payment.

In contrast to the industries, it is unlikely that at the company level employers will broaden the scope of their pension schemes to include all employees, as this is not a very realistic prospect from a financial point of view. Neither does the OPL require all white- and blue-collar workers to be covered by the same company pension scheme with the same pension benefits. The OPL still allows employers to make a distinction between their employees as long as the category is objectively justified and no longer based merely on a distinction between blue-collar and white-collar work (Doyen, 2014: 272-273).

\section{In search of a valid alternative category that complies with the principle of non-discrimination}

If companies and industries seek to continue to limit the material scope of their pension schemes to certain employees after the implementation of the unified status, they must pay attention to the principle of non-discrimination in order to find a valid alternative category. Article 14 OPL states that 'any discrimination between employees, affiliates and beneficiaries shall be prohibited'. The law does not list all forbidden grounds of discrimination, which corresponds to an open prohibition of discrimination: all distinctions must pass this non-discrimination test. Throughout this nondiscrimination test, the employer or industry will always have the opportunity to justify differential 
treatment, except for the specific grounds mentioned in the Anti-discrimination Law ${ }^{44}$ and, of course, with respect to the unified status. The concept of non-discrimination in the OPL ${ }^{45}$ corresponds to the interpretation of the CJEU (Sommerijns, 2003: 595-596).

The first important step in identifying a possible discriminatory treatment is the comparability test. Since real-life situations are seldom completely identical, it is essential to define which criteria are relevant while determining the comparability of two situations. Individuals who differ only in terms of irrelevant criteria will not find themselves in an identical, but nevertheless still in a comparable situation (Sommerijns, 2003: 595-596). Unfortunately, there are no clear guidelines for this delicate exercise (Bayart, 2004: 104-105). However, the Belgian legislator has decided no longer to accept solely the status of a blue-collar or white-collar worker as a relevant criterion. ${ }^{46}$ Although this will clearly facilitate the comparability test with respect to the unified status, the OPL remains strict on acceptance of a valid comparator: the OPL does not allow a disadvantaged employee to compare themself with a hypothetical person, ${ }^{47}$ as the CJEU would within the context of equal pay (Borelli, 2018: 182). The unified status will therefore have to be respected only where both blue- and white-collar workers are employed simultaneously (De Somviele and Van Damme, 2014: 155). The next steps in the discrimination test could be described as the 'actual equality test'. Firstly, a justification can only succeed when the criterion used to distinguish between employees is objective (Barret, 2003: 135). Thereafter, the court will verify, in accordance with CJEU case law, whether a legitimate aim is being pursued. Finally, the court must establish whether the means deployed are appropriate and necessary to achieving this objective. ${ }^{48}$

As previously established, the unified status has had a positive effect on the number of affiliates at the industry-wide level. However, it remains uncertain whether it can also enhance the participation rate of company pension schemes as employers often granted benefits exclusively to white-collar workers as part of a specific wage policy. In light of this policy, it may be understandable for an employer to search for an alternative solution rather than allow all their employees to join the pension scheme. The employer could opt to provide a pension scheme only for employees who reached a certain level within the company, for example managerial staff, as this alternative would most likely pass the nondiscrimination test. Within a large organisation, the existing job classification might also offer a solid basis for differentiating between employees regarding access to occupational pension schemes.

\footnotetext{
44 In Belgium, 19 criteria are 'protected' by anti-discrimination legislation, which goes beyond the mere transposition of European directives. These 'protected grounds' are race, skin colour, nationality, ancestry, national or ethnic origin, disability, philosophical or religious beliefs, sexual orientation, age, wealth, civil status, political beliefs, trade union membership, state of health, physical or genetic characteristics, birth, social background, gender and language (Law of 10 May 2007 pertaining to the combat of discrimination, Official Journal 10 May 2007).

45 Preparatory works OPL, Opinion of the Council of State no. 31.338/1, Chamber 2000-2001, no. 50-1340/001, 136.

${ }^{46}$ Another interpretation of the law would completely erode the unified status, which in my view would be an interpretation contra legem. This statement is supported by the Draft law on the unified status in occupational pensions, Chamber 2013-2014, no. 53-3399/002, 31.

${ }^{47}$ Draft law on the unified status in occupational pensions, Chamber 2013-2014, no. 53-3399/002, 32.

${ }^{48}$ Bilka, para 37.
} 
Although distinguishing between blue- and white-collar workers is not prohibited by the EU, maintaining it may lead to indirect discrimination on other protected grounds at the European level. A very brief overview of the extent of possible interference with other discrimination grounds follows. Firstly, the distinction between blue-collar and white-collar workers is not always gender neutral. In Belgium, for example, the blue-collar population is still predominantly male, while amongst white-collar workers a majority are female:
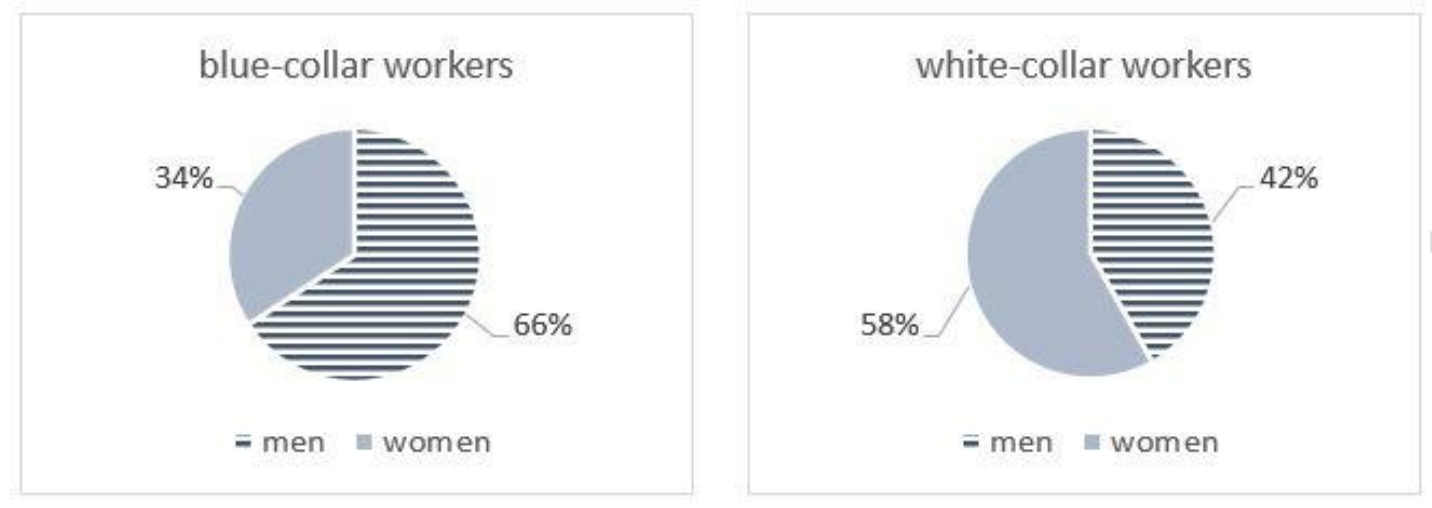

Figure 3. Unequal gender distribution between blue-collar and white-collar workers in Belgium (NSSO 2020: 32-33)

Because of this unequal gender distribution, a division between blue-collar and white-collar employees (regardless of the wording used to describe this category in the pension scheme) may amount to indirect discrimination on the basis of gender if there is no objective justification. The principle of equal pay between women and men may therefore play a role in assessing whether an alternative to the distinction based on blue-collar and white-collar status is valid. Secondly, the distinction between blueand white-collar workers may lead to indirect discrimination based on racial or ethnic origin, ${ }^{49}$ as nonnatives are over-represented in the blue-collar population (Bayart, 2004: 461-462). These interferences provide an opportunity to challenge an infringement of the Belgian unified status on a European level. Equally important in practice, this short analysis illustrates that an employer must be vigilant about not discriminating on other grounds in its search for a valid alternative for blue- and white-collar workers.

\section{A salary-based pension formula instead}

An employer or industry could also decide to grant all employees access to the pension scheme, while preserving a differentiation through a pension formula based on wages. As a result, the organiser of such a pension scheme would greatly reduce the risk of discrimination, even though not every employee accrued the same supplementary pension. In addition to being a safe choice, this option is also very easy to manage. If the employer or industry wishes to add a further level of wage differentiation for the highest salaries, a 'split pension formula' may be a solution. Higher incomes face a lower replacement rate by the statutory pension if the latter is capped with a wage limit. ${ }^{50}$ With a 'split pension formula', a higher contribution is paid for income above the wage limit for the statutory pension than for income below the limit. By using this advanced pension formula, the drop in income

\footnotetext{
${ }^{49}$ Council Directive 2000/43/EC of 29 June 2000 implementing the principle of equal treatment between persons irrespective of racial or ethnic origin, OJ $2000 \mathrm{~L} 180$.

50 This ceiling refers to the amount up to which the salary is taken into account for the statutory pensions. In Germany and Luxembourg, the ceiling also limits social security contributions, which are not capped in Belgium. C-354/16 Kleinsteuber ECLI:EU:C:2017:539, paras 33 and 37; Flohimont (2013: 219-220), Doyen (2007: 22-23).
} 
upon retirement is better remediated than with a simple pension formula, making it a pertinent distinction from a pension perspective. Moreover, it remains a safe way of differentiating, since the CJEU $^{51}$ has accepted this formula whenever the wage limit in the occupational pension formula coincides with the wage limit for the statutory pension (Knoops, 2018: 318-319).

In the past, the lower average wages for blue-collar workers compared to those for white-collar workers were cited as an explanation (or even justification) for a more favourable pension scheme for whitecollar workers. Due to the wage ceiling in the statutory pensions in Belgium, many well-paid whitecollar workers are confronted with a capped statutory pension, which means that their replacement income ratio upon retirement will be lower (European Commission, 2018b: 10). To compensate for this, pension schemes for white-collar workers only were installed at company level. However, the more limited income drop of many blue-collar workers upon retirement cannot justify the distinction in pension schemes on the sole basis of the status of blue-collar or white-collar worker. Firstly, the average wage gap between blue- and white-collar workers is blurring, making this position more of a bias. Secondly, it is difficult to justify this distinction based on a generalisation such as an average wage. After all, there are well-paid blue-collar workers and poorly paid white-collar workers. The well-paid bluecollar worker will be faced with a capping of his/her statutory pension while the salary of the poorlypaid white-collar worker will not exceed the pension ceiling. However, by basing a pension scheme on the assumption of an average wage per status, the blue-collar worker's income drop is not compensated for, while the white-collar worker is overcompensated. It is rightly argued that it is far more appropriate to base income-related diversity on the wage itself, rather than on the less accurate criterion of the worker's status (Stevens, 2008: 436-437). The split pension formula mentioned above therefore responds perfectly to an employers' need to compensate for the income drop for high earners.

\subsection{The level of benefits in occupational pension schemes}

In addition to broadening the scope of occupational pensions, strengthening their quality is also vital to establishing a democratic second pension pillar. However, Figure 2 illustrates that within the popular industry-wide pension schemes only limited benefits are accrued.

\section{Current state of play}

Figure 2 shows that industry-wide pension schemes are still struggling with low contributions in comparison to company schemes. In 2019, the average vested reserves per employee amounted to only 2,475 euros in industry-wide pension schemes, compared to 27,237 euros in company schemes (Figure 2). At the industry level, the more recent defined contribution schemes are even more austere, offering an average vested reserve of only 1,404 euros with an average final lump-sum payment of 2,246 euros (FSMA, 2019: 15-16). On a rough estimate, this vested reserve would give entitlement to a monthly annuity of merely 4 euros (Court of Audit, 2020: 55). These numbers show that with the introduction of industry-wide pension schemes, the quality of pension accrual has not evolved at the same rate as its distribution.

\footnotetext{
${ }^{51}$ Kleinsteuber, para 38.
} 
Additionally, one must be cautious about differences between contribution levels in pension schemes, in particular at the company level. Not only are employers and industries free to choose whether to install a pension scheme or not, but they are also free to determine the level of benefits they wish to grant. As a result, the average amount of vested reserves is not equally distributed across all affiliates and a closer look reveals major differences behind this number. In 2020, the median value of reserves at the company level (5,963 euros; FSMA, 2020: 8) was much lower than the average value $(27,230$ euros; Figure 2), revealing that the company scheme benefits were not equally distributed among all affiliates. This uneven distribution of benefits can be observed at the industry level as well, although the disparity is less pronounced with a median value of 749 euros (FSMA, 2020: 8) compared to an average vested reserve of 2.475 euros (Figure 2).

Still, these median values conceal a significant diversity. In accordance with the numbers cited above, the Belgian Court of Audit pointed out an important disparity in the distribution of pension reserves in Belgium. The Court notes that in 2017, 1 per cent of the population of pensioners received as much as 20 per cent of all supplementary pension payments. In contrast, 70 per cent of the population who received a supplementary pension had to share as little as 10 per cent of the lump-sum total (Court of Audit, 2020: 52-53). The Court concluded that this large disparity could threaten the efficiency of public policy, as the social and tax incentives have an important impact on public finances, while mainly benefiting only a happy few.

\section{Possible impact of the unified status}

As mentioned above, the unified status led to a harmonisation of some industry-wide pension schemes at a higher level of benefits. Still, there is no guarantee that these employees will accrue higher occupational pensions, as the technique of opting out (art. $9 \mathrm{OPL}$ ) could be used to avoid accumulating occupational pensions at industry and company levels (Doyen, 2014: 274).

To certain blue-collar or white-collar workers who were previously left out of the second pension pillar, the unified status could bring about an improvement. This improvement will, however, be limited as it will still stand at the low level of contributions which is common in 'open' pension schemes. The more generous a pension scheme is, the more likely it becomes for the employer to look for an alternative category in order to avoid having to allow too many employees to join it (Pâques, 2017: 10). This is understandable from a financial perspective, especially since the onset of the Covid-19 pandemic. Moreover, pension contributions do have to respect the legal wage moderation (De Somviele and Van Damme, 2014: 164), which offers little room for raises in Belgium..$^{52}$ In that respect, it is improbable that the unified status will bring about major shifts in the overall level of occupational pensions in Belgium.

\section{Conclusion}

This analysis is a reminder that non-discrimination law does not guarantee an improvement for all employees, as they could also be treated equally at a lower level of benefits without any infringement of the law. Within the context of equal pay, the CJEU clearly stated that there is no obligation to level

\footnotetext{
52 According to recent calculations by the Central Economic Council, the maximum margin available for the evolution of labour costs for the period 2021-2022 is 0.4 per cent, on top of an expected inflation indexation of 2.8 per cent. Available at: https://www.ccecrb.fgov.be/p/fr/812/rapport-technique-du-secretariat-2020-sur-lamarge-maximale- disponible-pour-l-evolution-des-couts-salariaux.
} 
up. Counting on non-discrimination law as the engine for improving the second pension pillar would therefore be unrealistic.

These general findings have also been found to apply in the specific Belgian case of the unified status among blue-collar and white-collar workers with regard to occupational pension schemes. Although the OPL bans the distinction between blue- and white-collar workers from occupational pension schemes, it does not prescribe at what level equality should be reached. Furthermore, even in the highly unlikely event that every employer and industry were to opt for the most beneficial scheme, most employees would still not receive a generous occupational pension. Although Belgium has attained remarkably broad coverage by occupational pensions, the quality of the second pension pillar is rather poor as the level of vested reserves remains low. While Belgian occupational pension schemes, in accordance with the Bismarckian tradition, only need to fulfil a complementary role to the state pension, the lack of substantial savings still means that a pensioner will not be able to rely on their occupational pension to provide a significant supplement to their state pension (European Commission, 2018a: 81). In 2017, the median value of the second pension pillar constituted only 1.6 per cent of the total income of pensioners in Belgium (Court of Audit, 2020: 53-54). We can therefore conclude that the quality of the second pension pillar in Belgium is still low and it is unlikely that the unified status will be powerful enough to improve that quality.

In conclusion, while non-discrimination law has a strong added value in abolishing differences in treatment, it would be erroneous to expect it to improve the level of occupational pensions. If there is a sincere desire to develop a high-quality second pension pillar, politicians must take the initiative to install specific supportive measures to stimulate its development, separately from non-discrimination law.

\section{Acknowledgement}

The author expresses her gratitude to the anonymous referees and the guest editors for their comments and suggestions.

\section{Declaration of conflicting interests}

The author(s) declared no potential conflicts of interest with respect to the research, authorship, and/or publication of this article.

\section{Funding}

The author(s) received no financial support for the research, authorship, and/or publication of this article.

\section{ORCID iD}

Sarah Knoops https://orcid.org/0000-0002-3003-1495

\section{References}

Barrett G (2003) Re-examining the concept and principle of equality in EC law. Yearbook of European law. 22: 117-153.

Bayart C (2004) Discriminatie tegenover differentiatie. Arbeidsverhoudingen na de Discriminatiewet Arbeidsrecht na de Europese Ras- en Kaderrichtlijn. Brussels: Larcier.

Berns L and Schmit P (2009) Les régimes complémentaires de pensions sous l'aspect du droit du travail. In: Régimes complémentaires de pension au Luxembourg - Bilan et perspectives dix ans aprés la loicadre. Louvain-la Neuve: Anthemis, pp.99-118. 
Bogg A, Costello C and Davies ACL (2016) The Role of the Court of Justice in labour law. In: Bogg A et al. (eds) Research handbook on EU labour law. Cheltenham: E. Elgar Publishing, pp.114-149.

Borelli S (2018) Article 157 TFEU. In: Ales E et al. (eds) International and European labour law - Articleby-article commentary. Baden-Baden: Nomos Verlagsgesellschaft, pp.209-214.

Court of Audit (2020), Occupational pensions - Efficiency of public policy on social and tax incentive. Report to the federal parliament. Available at: https://www.rekenhof.be/EN/Publications/Fiche.html?id=29c172da-fde3-4f90-afe5-b284153d1419.

Debaenst B (2004) Charles-Xavier Sainctelette en de geboorte van de moderne arbeidsovereenkomst in België. In: Debaenst B (ed) Van status tot contract. De arbeidsovereenkomst in België vanuit rechtshistorisch perspectief. Brugge: Die Keure, pp.43-70.

De Brabanter V et al. (2004) Aanvullende pensioenen voor werknemers. Mechelen: Kluwer.

De Somviele I and Van Damme A (2014) In 10 jaar tijd naar een eenheidsstatuut op vlak van aanvullende pensioenen. Oriëntatie. 6: 150-165.

Delogne F (2014) Régimes complémentaires de pension (2e partie): statut unique ouvriers/employés et informations des alliés sur leurs droits à pension. Forum de l'assurance. 147: 185-191.

Denys M, Pratt D and Stevens Y (2020) A comparative analysis of the information duties in Belgian and American occupational pensions. European Journal of Social Security. 1: 39-63.

Devoet C (2019) Le paysage des pensions complémentaires professionnelles - Partie II. Forum de l'assurance. 197: 131-135.

Doyen P (2007) Les pensions complémentaires au Grand-Duché de Luxembourg. Waterloo: Kluwer.

Doyen P (2014) Pensions complémentaires d'entreprises: I'arrivée à maturité? Bulletin des Assurances. 3: $271-284$.

Engels C (1992) Het onderscheid werkman/bediende. Een ongrondwettige discriminatie in strijd met de artikelen 6 en 6bis van de Belgische Grondwet, Rechtskundig Weekblad. 22: 729-742.

European Commission (2018a) Pension adequacy report 2018 - Current and future income adequacy in old age in the $E U$, volume 1.

European Commission (2018b) Pension adequacy report 2018 - Current and future income adequacy in old age in the $E U$, volume 2.

Financial Services and Markets Authority (FSMA) (2019) Biennial report on the sectoral pension schemes, cover period 2016-2017. Available at: https://www.fsma.be/fr/rapport-bisannuel

Financial Services and Markets Authority (FSMA) (2020) Annual sectoral overview 'The second pension pillar in the picture' at 1 January 2020, published 20 November 2020. Available at: https://www.fsma.be/fr/news/le-deuxieme-pilier-de-pension-en-images-apercu-2020

Flohimont V (2013) Gelijkheid in de pensioenregelingen voor ambtenaren, werknemers en zelfstandigen. Brugge: die Keure.

Knoops S (2018) Occupational pension schemes for part-time workers: Equality in the eye of the beholder? European Journal of Social Security. 4: 309-324.

Knoops S (2020) C-171/18 Ontoereikende maatregel om discriminatie op te heffen (case note on CJEU C-171/18 Safeway Ltd ECLI:EU:C:2019:839). SEW Tijdschrift voor Europees en economisch recht. 5: 249254. 
Masselot A and McLellan B (2018) Directive 86/378/EEC on equal treatment in occupational social security and pension schemes. In: Ales E et al. (eds) International and European labour law - Article-byarticle commentary. Baden-Baden: Nomos Verlagsgesellschaft, pp.481-494.

Mbala Lutama D (2019) Égalité de genre et facteurs actuariels. Influence de la jurisprudence Européenne. Chroniques de droit social. 07-08: 229-257.

National Labour Council (NLC) (2019) Opinion No 2.155 'Harmonisation of the status of bluecollar/white-collar worker - Occupational pensions - Application of the law of 5 of May 2014 - Problems of interpretation'. Available at: http://www.cnt-nar.be/AVIS/avis-2155.pdf.

National Labour Council (NLC) (2020) Report No 117 'Harmonisation of the status of blue-collar/whitecollar worker - Occupational pensions - Article 14/4 $\S 2$ OPL'. Available at: http://www.nar.be/RAPPORT/rapport-117-FR.docx.

National Social Security Office (2020) Labour market analysis: detailed quarterly data - Third quarter of 2020. Available at: https://www.onss.be/stats/analyse-du-marche-de-lemploi-donnees-trimestriellesdetaillees\#introduction.

Neuvonen PJ (2016) From a 'relative' to a 'relational' equality: rethinking comparability in the light of relational accounts of social justice. In: Cuypers D and Vrielink J (eds) Equal is not enough. Antwerpen: Intersentia, pp.135-153.

Nys I, Stevens Y and Forman J (2017) Early access to occupational pension plans. European Journal of Social Security. 2: 186-206.

Pâques S (2017) Le point sur l'harmonisation ouvrier/employé dans les pensions complémentaires. Orientations. 6: 2-17.

Ravelli, F (2012) The ECJ and supplementary pensions discrimination in EU law. European Journal of Social Law, 1: 51-68.

Ring P, Ervik R and Skogedal Lindén T (2020) Justifying pension reforms: Comparing policy discourses in Norway and the UK. European Journal of Social Security. 3: 306-326.

Sommerijns L and De Wilde I (2003) Gelijkheid anders dan op grond van geslacht in de aanvullende pensioenen. Tijdschrift voor Sociaal Recht / Revue de Droit Social. 4: 585-628.

Sommerijns L (2009) Discriminatie in aanvullende WAP-pensioenstelsels. Tijdschrift voor Sociaal Recht / Revue de Droit Social. 2: 131-285.

Stevens Y (2008) Onderscheid tussen arbeiders en bedienden in aanvullende pensioenen. Tijdschrift voor Sociaal Recht / Revue de Droit Social. 3: 433-437.

Strauss K (2013) Equality, fair-mutualisation and the socialisation of risk and reward in European pensions. In: Countouris $\mathrm{N}$ and Freedland $\mathrm{M}$ (eds) Resocialising Europe in a time of crisis. Cambridge: Cambridge University Press, pp.333-350.

Ulander-Wänman C (2019) The Swedish occupational pension scheme ITP2 can be discriminatory on elderly workers. In: Mannelqvist R et al. (eds) Festskrift Till Örjan Edström. Umeå: Umeå University, pp.485-499.

Van Peer M and Hélard H (2009) Évolution de design et du financement des régimes complémentaires de pension entre 1999 et 2009. In: Régimes complémentaires de pension au Luxembourg - Bilan et perspectives dix ans aprés la loi-cadre. Louvain-la Neuve: Anthemis, pp.153-170. 